\title{
General Practitioners' Perspective towards Healthy Ageing In Indonesia
}

\author{
Ray Wagiu Basrowi*, Tonny Sundjaya, Deni Krisnamukti, Bertri Maulidya Masita
}

\begin{abstract}
Background: The rapid ageing population among older adults from 2020 to 2040 has led to an emerging focus as this group begins to experience ageing and has a higher risk of having chronic illness of non-communicable diseases. Therefore, it is important to provide General Practitioners (GPs) with adequate knowledge and attitude of healthy ageing to ensure the quality of health service among older adults.

Objectives: To identify the perspective of general practitioners including the knowledge, attitude and practice towards adult health and nutrition to support healthy ageing in Indonesia.

Methods: An online survey was conducted among 100 general practitioners registered at the Indonesian Medical Council (KKI) and domiciled in the Greater Jakarta area and outside the Jabodetabek area. The sample recruitment process was carried out using the Alomedika online application. All data were analyzed using SPSS software.

Results: Almost all (92\%) of respondents who took this survey had a supportive attitude in providing additional nutrition to adults to support healthy ageing. About $76 \%$ of the respondents did so by recommending milk. However, in terms of knowledge, around $67 \%$ of the respondents showed inadequate results, especially about physiological changes that occurred in adults. There is no statistically significant difference between respondents' demographic characteristics and all perspectives measured in this study (i.e., knowledge, attitude and practice)

Conclusions: The study indicates that it is important to educate general practitioners about the healthy aging process in order to maintain general practitioners' attitudes and behavior in health services to support the success of achieving healthy aging in Indonesia.
\end{abstract}

Keywords: health ageing, nutrition, perspective, General Practitioner, Indonesia

\author{
*Correspondent: \\ ray.basrowi1@danone.com \\ Ray Wagiu Basrowi \\ Danone SN Indonesia \\ Published by Universitas Airlangga and IAGIKMI
}

\section{INTRODUCTION}

The Indonesia population aged 60 years or over is estimated to increase from $10.1 \%$ in 2020 to $18 \%$ of the total population in 2040, while the current pre-senior (4550 years) population in 2020 to 2040 will increase from $10.1 \%$ to $17.5 \%{ }^{1}$ The life expectancy and the number of the elderly population have increased dramatically, resulting in an populous ageing population, with middleaged adult between 45-60 years old experience in the signs of ageing. The expected growth in the ageing population in Indonesia meets a challenge to health care system. Currently, the health care system focuses on the most prevalent public health problems such as stunting and anaemia among pregnant mothers with prevalence of $30.8 \%$ and $48.9 \%$, and high cases of non-communicable disease such as stroke (14.2\%), heart disease $(2.4 \%)$ and diabetes (3.88\%) among older adults which have excessively contributed to national health insurance expenditure 2,3 According to $\mathrm{MOH}$, the limited of geriatric care unit in Indonesia has also become an issue ${ }^{3}$

Globally, the leading cause of death in adult and senior population is non-communicable disease, with around $2 / 3$ of mortality cases caused by hypertension, anemia, diabetes mellitus, heart disease, arthritis and stroke ${ }^{4}$ Basic health research 2018 shows that common chronic conditions in senior adults (45-54 years old) are hypertension, diabetes mellitus, heart disease and stroke with prevalence of $45.32 \%, 3.88 \%, 2.4 \%$ and $14.2 \%$, respectively. Besides, diabetes and hypertension are increasing approximate about $0.58 \%$ and $9.72 \%$ compared to year 2013. 5,6 Furthermore, nutrition related problem such as overweight (16.2\%) and obese (26\%) among adults (50- 54 years old) have also become major problems that contribute to the increasing cases of noncommunicable disease. ${ }^{2,4}$

According to the 2014 total diet study, the proportion of older adults ( $>55$ years old) with energy intake below $70 \%$ RDA is $44.6 \%$, with low protein intake $(45.8 \%)$ and particularly from the plant-based source only. In addition, inadequate fibre intake (below RDA) is observed in $90 \%$ of the adult population. ${ }^{7}$ Moreover, the senior adults have suffered micronutrient deficiencies due to the lack of fruits and vegetable intake. The high intake of energy-dense food, saturated fat, low intake of fruit and vegetables have caused an increased risk of 
chronic illness in the adult population. ${ }^{8,9}$. Older adults are more likely to have physical inactivity due to muscle and bone mass decreased. The lack of physical activity has been associated with obesity, diabetes, hypertension and heart disease. ${ }^{10}$ Poor diet and lack of physical activity lead to an increased prevalence of chronic conditions among elderly population. ${ }^{9}, 10$

According to WHO, healthy ageing is defined as the process of developing and maintaining physical, social, and mental health that enables well-being in older age, in order to improve the quality of life through the ageing period. Every older adult should be encouraged to have a long and healthy life, including access to quality health and social care. ${ }^{11}$ With an understanding on the importance of healthy ageing, older peoples' health will soon become an emerging focus as this group begins to experience ageing and has a higher risk of having chronic illness from non-communicable diseases, as well as due to their need for health services. ${ }^{11}$

General practitioners (GPs) is one of the first line health care practitioner in Indonesia who interact and provide health service to adult population in community basis. Numerous studies have showed that GP plays important and critical role in providing and maintaining the quality of health care service in primary level, especially the government-led health initiatives. ${ }^{12} \mathrm{~A}$ rapid ageing population has increased the demand for health services which are closer to home or primary health care (e.g. posyandu lansia), that requires GPs who are skilled and are able to manage older adults with complex health problems. ${ }^{13,14}$ Attitudes and perspectives of GPs will influence their interventions. ${ }^{13,14,15}$ However, the recent review has reported the less interest among medical doctors and students in caring for older people. Besides, some previous studies have showed that the knowledgebased interventions are not successful in improving attitudes of health professionals towards older people. ${ }^{15,}$ 16 There are only few studies which have investigated the knowledge and attitudes of GPs regarding healthy ageing in Indonesia. Therefore, this survey aims to identify the perspective of general practitioners, especially in terms of knowledge, attitude and practice towards adult health and nutrition to support healthy ageing in Indonesia.

\section{METHODS}

The cross-sectional study was conducted by applying an online survey among all General Practitioners (GP) between October to November 2020 based on the GPs database provided by medical-technology provider (Alomedika). The inclusion criteria were the certified GPs according to the Indonesia Medical Council (Konsil Kedokteran Indonesia (KKI)) registered database, who agreed to participate in the survey by signing in the informed consent, and agreed to complete the survey. A completed response rate was achieved resulting in a sample of 100 out of 102 GPs who enrolled the survey. Furthermore, the questionnaire was created using Survey Monkey online platform, and was distributed through email with informed consent form. The ethical clearance letter was obtained from the Faculty of Medicine of Atma Jaya University (18/10/KEP-FKIKUAJ/2020).

The questionnaire consisted of 15 multiple choice questions about the knowledge, attitude and practice of GPs toward healthy aging, mobility and the role of nutrition intervention based on the modified questionnaire from the previous studies. ${ }^{17,18,19}$ For the knowledge questions, the incorrect answer was given a 0 point, while the correct answer was given 1 point. The total scores were regarded as adequate if it was above $60 \%$, meaning that the GPs were having adequate knowledge. Meanwhile, if the total scores were below $60 \%$, the GPs were regarded of having inadequate knowledge. On the other hand, the total scores of attitude and practice were categorized as endorsed and neutral level of attitude regarding to the GPs answers $(60 \%$ or more of answers were considered endorsement). ${ }^{18}$ the data were analyzed using SPSS version 23 . The chi-square test was employed to analyze cross-tabulated data for bivariate analysis and linear regression model for multivariate analysis with all outcome variables taken at the $5 \%$ significance level $(p<0.05)$.

\section{RESULTS AND DISCUSSION}

One hundred GPs who had participated in the survey consist of $50 \%$ from Jakarta, Bogor, Depok, Tangerang and Bekasi (Jabodetabek) and 50\% from outside Jabodetabek. As shown in Table. 1, the majority of respondents are aged less than 40 years old. Furthermore, most of them have less than 10 years length of clinical services and are affiliated in private hospital or clinics.

As shown in Table 2 the majority of respondents have partial knowledge on topic related to physiological changes in healthy ageing and essential nutrients to maximize healthy ageing.

Regarding the attitude towards Adult Nutrition Intervention, most of the respondents have positive attitude towards adult nutrition intervention as seen in Table 3. This includes the importance of being healthy in older age, adequate nutrition intake to adult, nutrition intervention required by adult and herbal consumption as alternative treatment.

Moreover, nutrition intervention is recommended to adult by almost all respondents during their practice, while milk consumption is their majority recommendation to be given to adult patients with details that can be seen in Table 4 . 
Table 1. Demographic Characteristic of The Respondents

\begin{tabular}{lcc} 
& Variables & \multicolumn{2}{c}{$\begin{array}{c}\text { General practitioner } \\
\mathbf{N}=\mathbf{1 0 0}\end{array}$} \\
\hline Age of respondents & $\mathbf{n}$ & $\mathbf{\%}$ \\
$\leq 40$ years old & & 93 \\
$>40$ years old & 93 & 7 \\
Length of Practice & 7 & 85 \\
$\leq 10$ years & & 15 \\
$>10$ years & 85 & 50 \\
Domicile & 15 & 50 \\
Jabodetabek & & 30 \\
Non Jabodetabek & 50 & 70 \\
Affiliation & 50 & \\
$\quad$ Government hospital & 30 & \\
Private hospital / Clinic & 70 & \\
\hline
\end{tabular}

Table 2. Descriptive result of GPs Knowledge towards Healthy Ageing

\begin{tabular}{|c|c|c|c|c|}
\hline \multirow{2}{*}{ Knowledge Questions } & \multicolumn{2}{|c|}{$\begin{array}{l}\text { Complete Right Answers } \\
\qquad \mathbf{N}=100\end{array}$} & \multicolumn{2}{|c|}{$\begin{array}{l}\text { Incomplete Right Answers } \\
\qquad \mathrm{N}=100\end{array}$} \\
\hline & $\mathbf{n}$ & $\%$ & $\mathrm{n}$ & $\%$ \\
\hline $\begin{array}{l}\text { Physiological changes in healthy } \\
\text { ageing }\end{array}$ & 4 & 4 & 96 & 96 \\
\hline $\begin{array}{l}\text { Significant population increased } \\
\text { aged } 45-60 \text { years old }\end{array}$ & 68 & 68 & 32 & 32 \\
\hline $\begin{array}{l}\text { Impact of unachieved healthy } \\
\text { ageing }\end{array}$ & 50 & 50 & 50 & 50 \\
\hline $\begin{array}{l}\text { Factors that influence the } \\
\text { healthy ageing }\end{array}$ & 60 & 60 & 40 & 40 \\
\hline $\begin{array}{l}\text { Five essential nutrients to } \\
\text { maximize healthy ageing }\end{array}$ & 32 & 32 & 68 & 68 \\
\hline
\end{tabular}

Table 3. Descriptive result of GPs Attitude towards Healthy Ageing

\begin{tabular}{|c|c|c|c|c|}
\hline \multirow{2}{*}{ Questions } & \multicolumn{2}{|c|}{$\begin{array}{c}\text { Yes } \\
N=100\end{array}$} & \multicolumn{2}{|c|}{$\begin{array}{c}\text { No } \\
N=100\end{array}$} \\
\hline & $\mathbf{n}$ & $\%$ & $\mathbf{n}$ & $\%$ \\
\hline $\begin{array}{l}\text { Adult requires nutrition } \\
\text { intervention }\end{array}$ & 90 & 90 & 10 & 10 \\
\hline $\begin{array}{l}\text { Adequate nutrition can support } \\
\text { adult health status in the future } \\
\text { (e.g. reduce health care cost) }\end{array}$ & 95 & 95 & 5 & 5 \\
\hline $\begin{array}{l}\text { Herbal consumption is an } \\
\text { alternative health treatment }\end{array}$ & 66 & 66 & 34 & 34 \\
\hline $\begin{array}{l}\text { Healthy ageing is important in } \\
\text { the older age }\end{array}$ & 100 & 100 & - & - \\
\hline
\end{tabular}

Table 4. Descriptive result of GPs Practice of Adult Nutrition Intervention

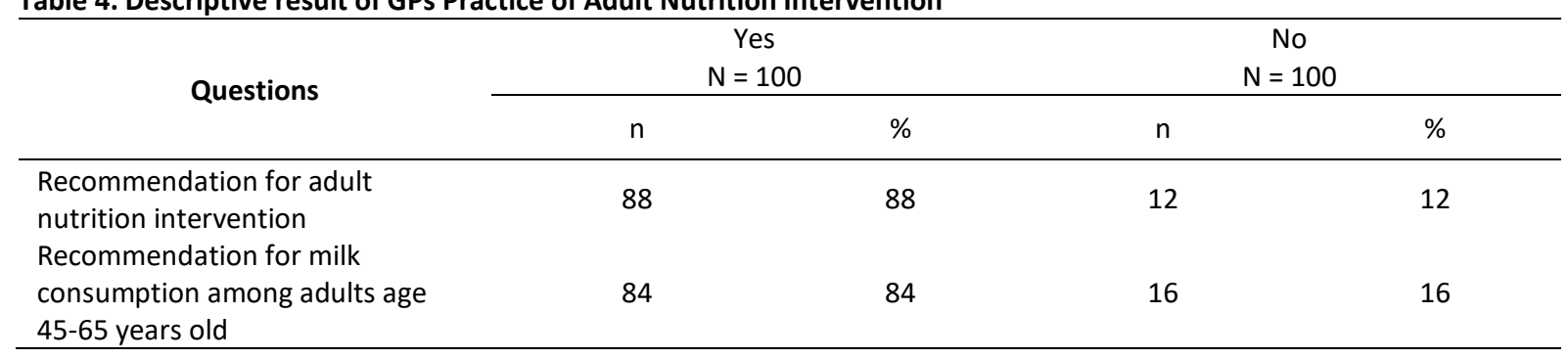


Table 5. Overview of Knowledge, Attitude and Practice on Adult Nutrition Intervention among General Practitioner

\begin{tabular}{|c|c|c|}
\hline \multirow[t]{2}{*}{ Variables } & \multicolumn{2}{|c|}{$\begin{array}{l}\text { General Practitioners } \\
\qquad N=100\end{array}$} \\
\hline & $\mathbf{N}$ & $\%$ \\
\hline \multicolumn{3}{|l|}{ Knowledge } \\
\hline Adequate & 33 & 33 \\
\hline Inadequate & 67 & 67 \\
\hline \multicolumn{3}{|c|}{ Attitude toward adult nutrition intervention } \\
\hline Endorsed & 92 & 92 \\
\hline Neutral & 8 & 8 \\
\hline \multicolumn{3}{|c|}{ Practice of adult nutrition intervention } \\
\hline Endorsed & 76 & 76 \\
\hline Neutral & 24 & 24 \\
\hline
\end{tabular}

Table 6. Multivariate Analysis of GP's Knowledge, Attitude and Practice of Healthy Ageing and Adult Nutrition Intervention Based on Demographic Characteristic

\begin{tabular}{|c|c|c|c|c|c|c|c|c|c|c|c|c|c|c|c|}
\hline \multirow{3}{*}{ Variables } & \multicolumn{4}{|c|}{$\begin{array}{l}\text { Knowledge towards } \\
\text { Healthy Ageing }\end{array}$} & \multirow{3}{*}{$\mathbf{P}$} & \multicolumn{4}{|c|}{$\begin{array}{c}\text { Attitude of Adult } \\
\text { Nutrition } \\
\text { Intervention } \\
\end{array}$} & \multirow{3}{*}{$\mathbf{P}$} & \multicolumn{4}{|c|}{$\begin{array}{c}\text { Practice of Adult } \\
\text { Nutrition } \\
\text { Intervention } \\
\end{array}$} & \multirow[t]{3}{*}{$\mathbf{P}$} \\
\hline & \multicolumn{2}{|c|}{ Adequate } & \multicolumn{2}{|c|}{ Inadequate } & & \multicolumn{2}{|c|}{ Endorsed } & \multicolumn{2}{|c|}{ Neutral } & & \multicolumn{2}{|c|}{ Endorsed } & \multicolumn{2}{|c|}{ Neutral } & \\
\hline & $\mathbf{N}$ & $\%$ & $\mathbf{N}$ & $\%$ & & $\mathbf{N}$ & $\%$ & $\mathbf{N}$ & $\%$ & & $\mathbf{n}$ & $\%$ & $\mathbf{n}$ & $\%$ & \\
\hline $\begin{array}{c}\text { Age of } \\
\text { respondents }\end{array}$ & & & & & 1.000 & & & & & 0.453 & & & & & 0.672 \\
\hline$\leq 40$ years old & 31 & 31 & 62 & 62 & & 86 & 86 & 7 & 7 & & 71 & 71 & 22 & 71 & \\
\hline$>40$ years old & 2 & 2 & 5 & 5 & & 6 & 6 & 1 & 1 & & 5 & 5 & 2 & 5 & \\
\hline $\begin{array}{l}\text { Length of } \\
\text { Practice }\end{array}$ & & & & & 0.768 & & & & & 0.344 & & & & & 0.752 \\
\hline$\leq 10$ years & 29 & 29 & 56 & 56 & & 79 & 79 & 6 & 6 & & 65 & 65 & 20 & 20 & \\
\hline$>10$ years & 4 & 4 & 11 & 11 & & 13 & 13 & 2 & 2 & & 11 & 11 & 4 & 4 & \\
\hline Domicile & & & & & 0.135 & & & & & 0.715 & & & & & 0.815 \\
\hline Jabodetabek & 20 & 20 & 30 & 30 & & 47 & 47 & 3 & 3 & & 37 & 37 & 13 & 13 & \\
\hline $\begin{array}{c}\text { Non } \\
\text { Jabodetabek }\end{array}$ & 13 & 13 & 37 & 37 & & 45 & 45 & 5 & 5 & & 39 & 39 & 11 & 11 & \\
\hline Affiliation & & & & & 0.675 & & & & & 0.694 & & & & & 0.364 \\
\hline $\begin{array}{c}\text { Government } \\
\text { hospital } \\
\text { Private }\end{array}$ & 9 & 9 & 21 & 21 & & 27 & 27 & 3 & 3 & & 21 & 21 & 9 & 9 & \\
\hline $\begin{array}{c}\text { hospital / } \\
\text { Clinic }\end{array}$ & 24 & 24 & 46 & 46 & & 65 & 65 & 5 & 5 & & 55 & 55 & 15 & 15 & \\
\hline
\end{tabular}

Majority of the respondents have inadequate knowledge toward adult nutrition intervention, which is indicated by GPs responses score below $60 \%$ correct answers. However almost all respondents show positive attitude and practice to endorse the nutrition intervention in adult.

From multivariate analysis, as seen in Table 6, there is no statistically significant difference between respondents' demographic characteristics and all perspectives measured in this study (i.e. knowledge, attitude and practice). On the other hand, those who are domiciled in Jabodetabek tend to have higher level of knowledge that can be one of considerations in designing follow up actions.
Adequate knowledge of health and nutrition might help to improve the quality of attitude and practice in order to educate and increase awareness of their adult patient towards adult nutrition in achieving healthy ageing. This is also supported by previous studies which have shown a significant relationship between nutrition and health ageing. Furthermore, older people with a good nutrition status can achieve healthy ageing. 19,20,21

Various studies have also shown that the lack of knowledge on ageing among health worker leads to improper attitude in healthy ageing preparation. ${ }^{14,15}$ The Findings of this study also confirm the particular matters. Endorsed attitude towards the recommendation of nutrition intervention in the form of 
tablet/supplementation or dairy milk may support a person during his/her ageing process. As people are ageing, they are found to be weaker and easily attacked by infections or illness. From a previous study, it is found that ageing is associated with the decline of the immune system due to instability of gut microbiota and the produce of fewer T immune cells. ${ }^{22}$ Besides, their natural muscle loss due to the change of nervous system and the loss of muscle tissue. ${ }^{23}$ Several studies have reported that milk consumption is associated with a lower risk of frailty and risk of dementia in older adult. ${ }^{24,25}$ On top of that, it is also well known that milk provides various important nutrients such as proteins, vitamins and minerals that have beneficial roles in maintaining bone health and various chronic diseases. ${ }^{26}$ Protein in milk can improve muscle maintenance in adult, since the rate of protein synthesizes is decreased during ageing process. ${ }^{23}$ As an excellent source of calcium and vitamin D, milk or dairy products is found to be linked with the reduction on osteoporosis and the cognitive decline rate among elderly people. ${ }^{27,28}$ Understanding all mentioned benefits above, it can be said that nutrition intervention is crucial in achieving healthy ageing.

Other aspects that can be found from the previous studies are older adults and elderly often experience physiological changes, e.g. low appetite that affects their nutritional intake. A previous study has noted that diet quality, as well as the amounts and types of food eaten over a prolonged period can lead to malnutrition in elderly and illness consequences, and are also related to health care costs. ${ }^{9,20}$ Drinking milk as a daily habit can boost the calories, proteins, vitamins and minerals that are essential for an adult's diet in preparing older age. ${ }^{24,25,26}$

From the existing evidences, it is known that nutrition intervention can be beneficial to adult in order to maintain their immune and health. However, routine nutrition intervention as supplementation has not yet become a recommendation. ${ }^{29}$ Knowing this fact, GPs can propose in identification of nutritional risk and the promotion of healthy dietary behaviours during the consultation. Furthermore, herbal supplement or tea which is used to support healthy ageing for thousands of years across the Asia region, is also used for traditional treatment and to cure various diseases. Some countries have considered traditional medicine as legal and safety, as well as a promising pharmacotherapy based on its efficacy in older people. ${ }^{30,31}$

Even though there is no statistical significant difference among GPs' perspective on their knowledge, attitude and practice across their domicile area (Jabodetabek and non-Jabodetabek), this study shows that non-Jabodetabek GPs have lower knowledge level. This might be related to access of knowledge. ${ }^{32,33}$ Therefore, for further action in designing the education, further exploration is needed to ensure GPs in all area that can grasp the required knowledge on healthy ageing in order to support achieving healthy ageing in Indonesia population.

This study has limitation in terms of design. Since the study is conducted with online survey, the subjectivity of respondents may potentially interfere with the study's objective. In addition, there are challenges to identify factors which influence the respondents in answering the given questions. Thus, more structured design and more respondents with varying domiciles are being recommended for further study which has similar interest with the aim of this study.

\section{CONCLUSION}

The rapid increase of ageing in Indonesia population has led to the importance of providing an essential strategy to improve the GPs knowledge, attitude and practice toward adult nutrition intervention. This can be carried out by providing them adequate knowledge. Opportunities for improvement are available for GPs through education which will also enable them to have a better contribution in achieving successful healthy ageing in Indonesia population.

\section{ACKNOWLEDGEMENT}

The author would like to acknowledge the funding contribution of Danone SN Indonesia for the publication for this article.

\section{CONFLICT OF INTEREST AND FUNDING DISCLOSURE}

This study was funded by Danone SN Indonesia.

\section{REFERENCE}

1. Indonesia, S. Statistical yearbook of Indonesia 2009. (2019).

2. Werdhani, R. A. Medical problem in Asia pacific and ways to solve it: The roles of primary care/family physician (Indonesia Xperience). J. Fam. Med. Prim. care 8, 1523 (2019).

3. Infodatin Kemenkes, R. I. Pusat Data dan Informasi Kementrian Kesehatan Republik Indonesia: Situasi dan Analisis Diabetes Mellitus. Jakarta Media Publis Kemenkes RI dikutip dari www. depkes. go. id (2014).

4. Organization, W. H. Noncommunicable diseases country profiles 2018. (2018).

5. RI, K. Kementerian Kesehatan Republik Indonesia. 2018. Pedoman Umum Gizi Seimbang. Jakarta Direktorat Jenderal Bina Kesehat. Masy. (2016).

6. KEMENKES, R. I. Kementerian Kesehatan Republik Indonesia, 2014. Pedoman Gizi Seimbang. Kemenkes Rl, Jakarta.

7. Data, P. P. \& Dokumen, P. Kementerian Kesehatan RI. (2014).

8. Shanti, K. M., Andarini, S., Mutiyani, M., Wirawan, N. N. \& Rahmawati, W. Asupan serat dan IMT wanita usia subur Suku Madura di Kota Malang. Indones. J. Hum. Nutr. 4, 1-11 (2017).

9. Robinson, S. M. Improving nutrition to support healthy ageing: what are the opportunities for intervention? Proc. Nutr. Soc. 77, 257-264 (2018).

10. Carstensen, G., Rosberg, B., Mc Kee, K. J. \& Åberg, A. C. Before evening falls: Perspectives of a good old age and healthy ageing among oldest- 
old Swedish men. Arch. Gerontol. Geriatr. 82, 35-44 (2019).

11. (WHO), W. H. O. Ageing: Healthy ageing and functional ability. Viitattu 8, 2020 (2020).

12. Syah, N. A., Roberts, C., Jones, A., Trevena, L. \& Kumar, K. Perceptions of Indonesian general practitioners in maintaining standards of medical practice at a time of health reform. Fam. Pract. 32, 584-590 (2015).

13. Alamri, B. H. \& Xiao, L. D. Health professionals' knowledge and attitudes toward older people in primary care in Saudi Arabia. Saudi Med. J. 38, 229 (2017).

14. Herzog, A., Gaertner, B., Scheidt-Nave, C. \& Holzhausen, M. 'We can do only what we have the means for'general practitioners' views of primary care for older people with complex health problems. BMC Fam. Pract. 16, 1-11 (2015).

15. Yang, Y., Xiao, L. D., Ullah, S. \& Deng, L. General practitioners' knowledge of ageing and attitudes towards older people in C hina. Australas. J. Ageing 34, 82-87 (2015).

16. Samra, R. et al. Medical students' and doctors' attitudes towards older patients and their care in hospital settings: a conceptualisation. Age Ageing 44, 776-783 (2015).

17. Basrowi, R. W., Wasito, E. \& Sundjaya, T. Perspective of Soy Formula and Fiber intake among Non-Cow's Milk Drinker Pediatric Patients; A Survey among Indonesian Health Care Practitioners. World Nutr. J. 4, 5-11 (2020).

18. Mohammed, R. F. \& Omar, A. A. A. Knowledge about elderly care and its relation to ageism attitude among undergraduate nursing students. Am. J. Nurs. 7, 73-78 (2019).

19. Runkawatt, V. et al. Kogan's Attitude Toward Old People: Evaluation of validity and reliability assessment among nursing students in Thailand, Myanmar, and Indonesia. Asian J. Public Opin. Res. 3, 145-155 (2016).

20. Cahyaningtyas, N. A., Sudiyanto, A. \& Soemanto, R. B. Socioeconomic determinants of healthy ageing and the contextual effect of peer group: A multilevel evidence from Blora, Central Java. J. Epidemiol. Public Heal. 4, 30-36 (2018).

21. Rahmawati, A., Pramantara, I. D. P. \& Purba, M. Asupan zat gizi mikro dengan fungsi kognitif pada lanjut usia. J. Gizi Klin. Indones. 8, 195-201 (2012).
22. Yaqoob, P. Ageing alters the impact of nutrition on immune function. Proc. Nutr. Soc. 76, 347351 (2017).

23. Du, Y., Oh, C. \& No, J. Advantage of dairy for improving aging muscle. J. Obes. Metab. Syndr. 28, 167 (2019).

24. Lana, A., Rodriguez-Artalejo, F. \& Lopez-Garcia, E. Dairy consumption and risk of frailty in older adults: a prospective cohort study. J. Am. Geriatr. Soc. 63, 1852-1860 (2015).

25. Ozawa, M. et al. Milk and Dairy Consumption and Risk of Dementia in an Elderly J apanese Population: The H isayama Study. J. Am. Geriatr. Soc. 62, 1224-1230 (2014).

26. Saito, A., Okada, E., Tarui, I., Matsumoto, M. \& Takimoto, H. The Association between Milk and Dairy Products Consumption and Nutrient Intake Adequacy among Japanese Adults: Analysis of the 2016 National Health and Nutrition Survey. Nutrients 11, 2361 (2019).

27. Lee, J., Fu, Z., Chung, M., Jang, D.-J. \& Lee, H.-J. Role of milk and dairy intake in cognitive function in older adults: a systematic review and metaanalysis. Nutr. J. 17, 1-15 (2018).

28. Sahni, S., Mangano, K. M., Kiel, D. P., Tucker, K. L. \& Hannan, M. T. Dairy intake is protective against bone loss in older vitamin D supplement users: the Framingham Study. J. Nutr. 147, 645-652 (2017).

29. Mike, L. A. \& Chan, L.-N. Nutritional Supplements in Older Adults.

30. Kwon, C.-Y., Lee, B., Chung, S.-Y., Kim, J. W. \& Kim, S.-H. Oriental herbal medicine for insomnia in the elderly with hypertension: A systematic review protocol. Medicine (Baltimore). 97, (2018).

31. de Souza Silva, J. E. et al. Use of herbal medicines by elderly patients: a systematic review. Arch. Gerontol. Geriatr. 59, 227-233 (2014).

32. Balogh, R. et al. Dementia in Hungary: General practitioners' routines and perspectives regarding early recognition. Eur. J. Gen. Pract. 26, 7-13 (2020).

33. Ng, N., Hakimi, M., Byass, P., Wilopo, S. \& Wall, $S$. Health and quality of life among older rural people in Purworejo District, Indonesia. Glob. Health Action 3, 2125 (2010). 